\title{
PENGARUH PEMAHAMAN, KUALITAS PELAYANAN, DAN SANKSI PERPAJAKAN TERHADAP KEPATUHAN WP PELAKU UMKM SESUDAH PENERAPAN PP NO.46 TAHUN 2013 (Survey Kantor Pelayanan Pajak Pratama Wonosari )
}

\author{
Suyanto* \\ Diana Alim Kholifah \\ Program Studi Akuntansi Fakultas Ekonomi \\ Universitas Sarjanawiyata Tamansiswa Yogyakarta \\ *iyantsuyanto@gmail.com
}

\begin{abstract}
This study was conducted to examine the effect of omprehension, quality of service, and tax penalties to the level of $i$ taxpayer compliance UMKM in KPP Pratama Wonosari. While this study was conducted to examine the effect of comprehension, quality of service, and tax penalties simultaneousuly level of taxpayer compliance UMKM in KPP Pratama Wonosari. This study uses the dependent variable is tax compliance while independent variable are of comprehension, quality of service, and tax penalties. The sampling technique that is taken sksidental sampling. Aksidental sampling is technique determination sample based spontaneity factor, meaning anyone inadertently meet with investigators and accordance with characteristics (traits) than that person is used as $s$ sample.
\end{abstract}

This study classified in quantitative research. Data collection procedures using a question are wich was distributed to the public filled by an taxpayer. While data analys techniques using multiple regression analysis bye the F-test, koefisien determine $R^{2}$, and T-test. Quality data test of validitas test and reliability test. The clasical assumption test of normaliy test, multicollinearity test, and heteroscedasticity test.

The result showed the Comprehension and quality of services significant positive effect on the level of compliance of taxpayer. While tax penalties not significant effect on the level of compliance of taxpayer. And simultaneousulycomprehension, quality of service, and tax penaltiessignificant positive effect on the level of compliance of taxpayer. Results of determination (R2) that show the influence of the kepauhan $70.7 \%$ and the remaining $29.3 \%$ is influenced by other factors.

Keywords: comprehension, quality of service, tax penalties, compliance

\section{PENDAHULUAN}

Sumber penerimaan negara berasal dari pajak, bukan pajak, dan hibah. Sumber Anggaran Pendapatan dan Belanja Negara (APBN) terbesar dari sektor pajak. Begitu besarnya peran pajak dalam APBN, maka usaha untuk meningkatkan penerimaan pajak terus dilakukan oleh pemerintah yang dalam hal ini merupakan tugas Direktorat Jenderal Pajak. Berbagai upaya dilakukan Direktorat Jenderal Pajak agar penerimaan pajak maksimal, antara lain adalah dengan ekstensifikasi dan intensifikasi pajak. Hal tersebut dilakukan dengan cara perluasan subjek dan objek pajak.

Peraturan Pemerintah Nomor 46 tahun 2013 adalah peraturan baru yang mengatur besarnya pajak terutang atas penghasilan wajib pajak (WP) dengan peredaran bruto teetentu dalam tahun pajak. Peraturan baru ini bersifat final dengan tarif $1 \%$ dari peredaran bruto. Dalam pajak ada beberapa hal yang terkait yaitu: orang atau badan (subjek pajak), barang atau bentuk sebagai dasar pengenaan pajak (objek pajak), dan tarif pajak. 
Tabel 1

Kepatuhan WP Pelaku UMKM Kreteria Pelaporan SPT KPP Pratama Wonosari Tahun 2014

\begin{tabular}{cccccccc}
\hline \multirow{2}{*}{$\begin{array}{c}\text { Jenis } \\
\text { WP }\end{array}$} & \multicolumn{4}{c}{ WP } & \multicolumn{4}{c}{ Realisasi Penyampaian SPT } & \multirow{2}{*}{$\begin{array}{c}\text { Rasio } \\
\text { Kepatuhan }\end{array}$} \\
\cline { 2 - 7 } & Terdaftar & Wajib SPT & KB & LB & Nihil & Total & Kepary \\
\hline Badan & 1.724 & 1.191 & 179 & 1 & 483 & 663 & $55,67 \%$ \\
OP & 4.328 & 3.349 & 416 & 1 & 604 & 1.021 & $30,49 \%$ \\
\hline
\end{tabular}

Sumber KPP Pratama Wonosari Tahun 2015

Tabel 1menjelaskan kepatuhan WP pelaku UMKM kreteria pelaporan SPT KPP Pratama Wonosari Tahun 2014 jumlah rasio kepatuhan WP 37,09\%. WP badan yang terdaftar yaitu 1.724 dengan wajib SPT yaitu 1.191, tetapi dalam realisasi penyampaian SPT terdapat $179 \mathrm{~KB}, 1 \mathrm{LB}$, nihil 483, dan diperoleh rasio kepatuhan $55,67 \%$. Sedangkan WPOP dari jumlah yang terdaftar 4.328 terdapat wajib SPT 3.349 dengan realisasi penyampaian SPT 416 KB, 1 LB, 604 nihil, dan diperoleh rasio kepatuhan $30,49 \%$.

\section{LANDASAN TEORI DAN PENGEMBANGAN HIPOTESIS Pemahaman WP}

Menurut Kamus Lengkap Bahasa Indonesia pemahaman adalah sesuatu hal yang kita pahami dan kita mengerti dengan benar.Sehingga dapat diartikan bahwa pemahaman adalah suatu proses, cara memahami, cara mempelajari sesuatu dengan baik supaya paham dan mempunyai pengetahuan

PemahamanWP terhadap peraturan perpajakan adalah cara WP dalam memahami peraturan perpajakan yang telah ada (Pancawati 2011 ). Menurut Fikriningrum (2012) Pemahamam merupakan kemampuan untuk menangkap makna dan arti dari bahan yang dipelajari. WP yang tidak memahami peraturan perpajakan secara jelas cenderung akan menjadi WP yang tidak taat. Jelas bahwa semakin paham WP terhadap peraturan perpajakan, maka semakin paham pula WP terhadap sanksi yang akan diterima bila melalaikan kewajiban perpajakan mereka. WP yang benar-benar paham, mereka akan tau sanksi adminstrasi dan sanksi pidana sehubungan dengan SPT dan NPWP.

Pemahaman adalah tingkat kemampuan yang mengharapkan seseorang mampu memahami arti, tujuan dan arti dari maksudnya. Dalam hal ini ia tidak hanya hapal secara verbalitas, tetapi memahami isi dari suatu peraturan yang ada, maka dapat mengubah, mengatur, menjelaskan, mendemonstrasikan, dan memberi contoh sehingga dalam hal ini mampu memberikan peningkatan dalam kepatuhan.

Untuk mengetahui pengetahuan dan pemahaman WP terhadap peraturan perpajakan, dapat dilihat dari beberapa hal yaitu:

Mengisi SPT dengan benar, 2) Mengetahui Manfaat akan pembayaran Pajak, 3) Selalu menghitung pajak dengan jumlah yang benar, 4) Selalu membayar pajak tepat waktu, 5) Melaporan SPT tahunan dengan baik dan benar.

Pemahaman mengenai hak dan kewajiban sebagai WP sangat dibutuhkan dalam melakukan kegiatan perpajakan. Apabila WP telah mengetahui dan memahami hak WP seperti penggunaan fasilitas umum, pemakaian jalan raya yang halus,pembangunan sekolah-sekolah negeri dan lain-lain, dan mengetahui kewajibannya sebagai WP seperti membayar pajak dan melaporkan SPT tepat waktu, maka mereka akan melakukan kewajiban perpajakannya (Fikriningrum 2012)

Dengan adanya self assesment system sebenarnya WP lebih diberikan kebebasan dan kemudahan tersendiri dalam melakukan kegiatan perpajakan, tetapi masih banyak WP yang kesulitan dalam menghitung jumlah pajaknya sendiri. Maka sebenarnya program self assesment system akan berjalan dengan baik jika WP paham tentang cara menghitung pajaknya. 
Dengan pemahaman yang didapat ditambah dengan kemudahaan yang diberikan oleh fiskus tidak meunutup kemungkinan WP meningkatkan kepatuhan perpajakan.

Pemahaman WP adalah ilmu dasar atau informasi dasar WP yang harus diketahui sebelum melakukan kewajiban perpajakan. Setelah WP paham akan peraturan yang dimaksud mulai akan tumbuh kesadaran dalam hal perpajakan. WP akan melakukan kepatuhan perpajakan jika mereka memahami peraturan dan manfaat akan perpajakan itu sendiri. WP yang tidak memahami peraturan perpajakan secara jelas cenderung akan menjadi WP yang tidak taat (Pancawati 2011).

Menurut Adiputra (2014) WP yang memiliki pemahaman tentang pajak, diharapkan menyadari bahwa peran pajak menjadi sangat penting yang akan digunakan untuk membiayai pengeluaran umum pemerintah untuk pencapaian tujuan pembangunan yang dapat memberikan kesejahteraan bagi rakyat. Selanjutnya pemahamanya tersebut bisa diimplementasikan dengan suatu tindakan yaitu pembayaran dan pelaporan SPT dan dengan sendirinya tumbuh sikap patuh. Karena pemahaman mendalam tentang perpajakan bukan hanya berguna bagi WP atau petugas pajak, melainkan juga bagi semua masyarakat umum karena hasil penerimaan pajak akan digunakan untuk fasilitas umum.

Ada bebearapa hal yang mendukung pemahaman WP untuk meningkatkan kepatuhan yaitu: Pertama, Perhatian: cara ini bisa dilakukan dengan sosialisasi, penyuluhan kepada pelaku UMKM. Kedua, Relevansi: mengemukakan relevansi peraturan yang berlaku dan menjelaskan manfaat serta tujuan pentingnya perpajakan. Ketiga, Kepercayaan: memberikan kepercayaan kepada WP yang telah menguasai maksut adanya pajak dan isi akan peraturan yang berlaku kepada WP lain yang masih kurang paham. Dari landasan teori diatas maka hipotesis yang penulis buat adalah

$\mathrm{H}_{1}$ : Pemahaman WP berpengaruh positif
terhadap kepatuhan WP Pelaku
UMKM

\section{Kualitas Pelayanan}

Pelayanan yang berkualitas menurut Supadmi (2009) adalah pelayanan yang dapat memberikan kepuasan kepada WP dan tetap dalam batas memenuhi standar pelayanan yang dapat dipertangung jawabkan serta harus dilakukan secara terus-menerus. Kualitas adalah suatu kondisi dinamis yang berhubungan dengan produk, jasa manusia, proses, dan lingkungan yang memenuhi atau melebihi harapan pihak yang menginginkannya.

Menurut Nafsi (2014) pelayanan adalah cara melayani (membantu mengurus atau menyiapkan segala kebutuhan yang diperlukan seseorang). Kualitas pelayanan merupakan suatu sikap atau pertimbangan global tentang keuangan dari suatu pelayanan (Putra 2009). Menrut Triyanto (2013) pelayanan yang baik yang dilakukan akan mendorong tingkat kepatuhan masyarakat dalam memenuhi kewajiban pajaknya. Pelayanan yang baik akan memberikan kenyamanan bagi WP (Jotopurnomo dan Mangoting 2013)

Menurut Oentari dan Mangoting (2013) Ada lima dimensi kualitas pelayanan jasa yang dapat dirincikan sebagai berikut: tangibles, atau bukti fisik, reliability, atau keandalan responsiveness, atau ketanggapan, assurance, atau jaminan dan empathy, yaitu memberikan perhatian yang tulus dan bersifat individual atau pribadi.

Tangibles (bukti fisik) yaitu kemampuan suatu perusahaan dalam menunjukkan eksistensi kepada pihak eksternal. Penampilan dan kemampuan sarana dan prasarana fisik perusahaan dan keadaan lingkungan sekitarnya adalah bukti nyata dari pelayanan yang diberikan oleh pemberi jasa, yang meliputi fasilitas fisik (gedung, gudang, dan lain sebagainya), perlengkapan dan peralatan yang dipergunakan (teknologi), serta penampilan pegawainya. Selain itu bukti langsung adalah fasilitas dan peralatan fisik serta penampilan karyawan yang professional.

Reliability (keandalan) yaitu kemampuan perusahaan untuk memberikan pelayanan sesuai yang dijanjikan secara akurat dan terpercaya. Kinerja harus sesuai dengan harapan pelanggan yang berarti ketepatan waktu, pelayanan yang sama, untuk semua pelanggan tanpa kesalahan, 
sikap yang simpatik, dan dengan akurasi yang tinggi. Keandalan ini mencakup dua hal pokok yaitu konsistensi kerja (performance) dan kemampuan untuk dipercaya (dependability). Hal ini berarti perusahaan memberikan jasanya secara tepat semenjak saat pertama (right the first time).

Responsiveness (ketanggapan) yaitu
suatu kemauan untuk membantu dan memberikan pelayanan yang cepat (responsif) dan tepat kepada pelanggan, dengan penyampaian informasi yang jelas. Membiarkan konsumen menunggu tanpa adanya suatu alasan yang jelas menyebabkan persepsi yang negatif dalam kualitas pelayanan. Selain itu daya tangkap adalah keinginan para staf untuk membantu para pelanggan dan memberikan pelayanan dengan tangga.

Assurance (jaminan) yaitu pengetahuan, kesopansantunan, dan kemampuan para pegawai perusahaan untuk menumbuhkan rasa percaya para pelanggan kepada perusahaan. Terdiri dari beberapa komponen antara lain komunikasi (communication), kredibilitas (credibility), keamanan (security), kompetensi (competence), dan sopan santun (courtesy). Selain itu jaminan mencakup pengetahuan, kemampuan, kesopanan, dan sifat dapat dipercaya yang dimiliki para staff, bebas dari bahaya, risiko, atau keragu-raguan.

Empathy yaitu memberikan perhatian yang tulus dan bersifat individual atau pribadi yang diberikan kepada para pelanggan dengan berupaya memahami keinginan konsumen. Dimana suatu perusahaan diharapkan memiliki pengertian dan pengetahuan tentang pelanggan, memahami kebutuhan pelanggan secara spesifik, serta memiliki waktu pengoperasian yang nyaman bagi pelanggan. Selain itu dapat didefinisikan kemudahan dalam melakukan hubungan, komunikasi yang baik, perhatian pribadi, dan memahami kebutuhan para pelanggan. Atau lebih singkatnya yaitu tingkat perhatian terhadap para pelanggan".

Dalam Keputusan Menpan Nomor 63 Tahun 2003 terdapat sepuluh prinsip-prinsip pelayanan prima sebagai berikut: 1) Kesederhanaanyaitu prosedur pelayanan publik tidak berbelit-belit, mudah dipahami dan mudah dilaksanakan; 2) kejelasan dalam prinsip ini ada beberapa hal yaitu: persyaratan teknis dan administratif pelayanan publik, unit kerja/pejabat yang berwenang dan bertanggungjawab dalam memberikan pelayanan dan penyelesaian keluhan/persoalan/sengketa dalam pelaksanaan pelayanan publik, dan rincian biaya pelayanan publik dan tata cara pembayaran; 3) kepastian waktu yaitu pelaksanaan pelayanan publik dapat diselesaikan dalam kurun waktu yang telah ditentukan; 4) akurasi yaituproduk pelayanan publik diterima dengan benar, tepat, dan sah; 5) keamanan yaitu proses dan produk pelayanan publik memberikan rasa aman dan kepastian hukum; 6) tanggung jawabyaitu pmpinan penyelenggara pelayanan publik atau pejabat yang ditunjuk bertanggungjawab atas penyelenggaraan pelayanan dan penyelesaian keluhan/persoalan dalam pelayanan publik; 7 kelengkapan sarana dan prasarana yaitu tersedianya sarana dan prasarana kerja, peralatan kerja dan pendukung lainnya yang memadai termasuk penyediaan sarana teknologi telekomunikasi dan informatika (telematika); 8) kemudahan akses yaitu tempat dan lokasi serta sarana pelayanan yang memadai, mudah dijangkau oleh masyarakat, dan dapat memanfaatkan teknologi telekomunikasi dan informatika; 9) kedisiplinan, kesopanan dan keramahan yaitu pemberi pelayanan harus bersikap disiplin, sopan dan santun, ramah, serta memberikan pelayanan dengan ikhlas; 10) kenyamanan, yaitu lingkungan pelayanan harus tertib, teratur, disediakan ruang tunggu yang nyaman, bersih, rapi, lingkungan yang indah dan sehat serta dilengkapi dengan fasilitas pendukung pelayanan, seperti parkir, toilet, tempat ibadah dan lain-lain.

\section{$\mathrm{H}_{2}$ : Kualitas pelayanan berpengaruh positif terhadap kepatuhan WP pelaku UMKM}

\section{Sanksi Perpajakan}

Menurut Jotopurnomo dan Mangoting (2013) sanksi merupakan hukuman negatif kepada orang yang melanggar peraturan, sehingga dapat dikatakan bahwa sanksi perpajakan adalah hukuman negatif kepada orang yang melanggar peraturan dengan cara membayar uang. Menurut Pranadata 
(2014)sanksi pajak merupakan alat kontrol yang mengontrol agar WP tetap memenuhi kewajiban perpajakannya dikarenakan dengan adanya kerugian yang akan didapat oleh WP apabila tidak membayarkan pajak yang secara otomatis akan membuat WP harus berpikir apabila tidak ingin memenuhi kewajiban perpajakannya. Sanksi perpajakan diberikan kepada WP agar WP mempunyai kesadaran dan patuh terhadap kewajiban pajak (Rutiyaningsih 2011). WP akan memenuhi kewajiban perpajakannya bila memandang bahwa sanksi perpajakan akan lebih banyak merugikannya (Jatmiko 2006).

Sanksi perpajakan diberikan kepada WP agar WP mempunyai kesadaran dan patuh akan kewajiban perpajakan (Rustianingsih 2011). Sanksi perpajakan yang diberikan secara tegas akan meningkatkan tingkat kepatuhan. Sanksi dalam perpajakan menjadi penting karena pemerintah lndonesia memilih menerapkan self assessment system dalam rangka pelaksanaan pemungutan pajak. Pemerintah telah menyiapkan rambu-rambu yang diatur dalam Undang-Undang Perpajakan yang berlaku agar pelaksanaan pemungutan pajak dapat tertib dan sesuai dengan target yang diharapkan. Apabila kewajiban perpajakan tidak dilaksanakan, maka ada konsekuensi hukum yang bisa terjadi karena pajak mengandung unsur pemaksaan. Konsekuensi hukum tersebut adalah pengenaan sanksi-sanksi perpajakan.

Dalam undang-undang perpajakan dikenal dua macam sanksi, yaitu sanksi administrasi dan sanksi pidana. Sanksi administrasi dapat dijatuhkan apabila WP melakukan pelanggaran, terutama atas kewajiban yang ditentukan dalam UU KUP dapat berupa sanksi administrasi bunga, denda dan kenaikan. Sedangkan sanksi pidana dapat berupa hukuman kurungan dan hukuman penjara. Pelaksanaan pengenaan sanksi perpajakan kepada WP dapat berupa sanksi administrasi saja, sanksi pidana saja atau keduaduanya.

Sanksi administrasi denda adalah jenis sanksi yang paling banyak ditemukan dalam UU Perpajakan. Terkait besarannya, denda dapat ditetapkan sebesar jumlah tertentu, presentasi dari jumlah tertentu, atau suatu angka perkalian dari jumlah tertentu. Pada sejumlah pelanggaran, sanksi denda ini akan ditambahkan dengan sanksi pidana. Pelanggaran yang dikenai sanksi pidana ini adalah pelanggaran yang sifatnya alpa atau disengaja.

Sanksi administrasi berupa bunga dikenakan atas pelanggaran yang menyebabkan utang pajak menjadi lebih besar. Jumlah bunga dihitung berdasarkan persentase tertentu dari suatu jumlah, mulai dari saat bunga itu menjadi hak/kewajiban sampai dengan saat diterima dibayarkan. Terdapat beberapa perbedaan dalam menghitung bunga utang biasa dengan bunga utang paiak.

Sanksi administrasi berupa kenaikan adalah sanksi yang paling ditakuti oleh WP. Hal ini karena bila dikenakan sanksi tersebut, jumlah pajak yang harus dibayar bisa menjadi berlipat ganda. Sanksi berupa kenaikan pada dasarnya dihitung dengan angka persentase tertentu dari jumlah pajak yang tidak kurang dibayar. Jika dilihat dari penyebabnya, sanksi kenaikan biasanya dikenakan karena WP tidak memberikan informasi-informasi yang dibutuhkan dalam menghitung jumlah pajak terutang.

Sanksi berupa denda pidana dikenakan kepada WP dan diancamkan juga kepada pejabat pajak atau pihak ketiga yang melanggar norma. Denda pidana dikenakan kepada tindak pidana yang bersifat pelanggaran maupun bersifat kejahatan.

Sanksi Pidana kurungan hanya diancamkan kepada tindak pidana yang bersifat pelanggaran. Dapat ditujukan kepada WP, dan pihak ketiga. Karena pidana kurungan diancamkan kepada si pelanggar norma itu ketentuannya sama dengan yang diancamkan dengan denda pidana, maka masalahnya hanya ketentuan mengenai denda pidana sekian itu diganti dengan pidana kurungan selamalamanya sekian.

Pidana penjara seperti halnya pidana kurungan, merupakan hukuman perampasan kemerdekaan. Pidana penjara diancamkan terhadap kejahatan. Ancaman pidana penjara tidak ada yang ditujukan kepada pihak ketiga, adanya kepada pejabat dan kepada WP.

Berdasarkan hasil wawancara kepada kepala KPP Pratama Wonosari. Penerpan sanksi terhadap PP No 46 tahun 2013 atas 
keterlambatan pembayaran pajak tidak diadakan. Hal itu dikarenakan pelaku UMKM sudah termasuk orang yang rela membagi hasil usahanya dengan negara ( tidak nmpang hidup) walaupun hanya $1 \%$ dari usahanya ( penjual di pasar, warung kelontong dll). Akan tetapi UMKM yang sudah mampu membuat laporan keuangan apabila ada keterlambatan akan ada tindakan khusus dari KPP Pratama (Koprasi dan KAP) yang peredaran brutonya dibawah $4,8 \mathrm{M}$.

$\mathrm{H}_{3}$ : Sanksi perpajakan tidak berpengaruh positif terhadap kepatuhan WP pelaku UMKM

\section{Kepatuhan WP}

Kepatuhan berasal dari kata dasar patuh, yang menurut Kamus Besar Bahasa Indonesia , patuh berarti suka menurut perintah, taat pada perintah atau aturan, berisiplin. Kepatuhan berarti tunduk atau patuh pada ajaran atau aturan. Menurut Nafsi (2014) WP yang patuh adalah WP yang taat dan memenuhi serta melaksanakan kewajiban perpajakannya sesuai dengan ketentuan peraturan perundangundangan perpajakan.

Menurut Cristian (2014) ada dua macam kepatuhan, yaitu kepatuhan formal dan kepatuhan material. Kepatuhan formal adalah suatu keadaan dimana WP memenuhi kewajiban secara formal sesuai dengan ketentuan dalam undang- undang perpajakan. Kepatuhan material adalah suatu keadaan di mana WP memenuhi semua ketentuan material perpajakan, yakni sesuai dengan isi dan jiwa undang- undang perpajakan. Kepatuhan material dapat juga memenuhi kepatuhan formal Supadmi (2009).

Kreteria sesuai pasal 17 C KUP Jis KMK Nomor 544/KMK.04/2000 Direktorat Jenderal Pajak tealah mengeluarkan Kriteria WP Patuh. WP Patuh adalah WP yang ditetapkan oleh Direktorat Jenderal Pajak sebagai WP yang memenuhi kriteria tertentu yang dapat diberikan pengembalian pendahuluan atas kelebihan pembayaran pajak. Kriteria WP Patuh tersebut antara lain sebagai berikut: 1) Tepat waktu dalam menyampaikan Surat Pemberitahuan Pajak baik Pajak Tahunan maupun Pajak Masa; 2) tidak mempunyai tunggakan pajak untuk semua jenis pajak, kecuali telah memperoleh izin untuk mengangsur atau menunda pembayaran pajak. Tidak pernah dijatuhi hukuman karena melakukan tindakan pidana dibidang perpajakan dalam jangka waktu 10 tahun terakhir yang mengakibatkan kerugian Negara; 3) apabila dilakukan pemeriksaan pajak, koreksi fiscal yang dilakukan oleh pemeriksa pajak untuk setiap jenis pajak yang terutang tidak lebih dari $10 \%$ (sepuluh persen) dilihat dari penghasilan bruto (PKP).

\section{Kerangka Teori}

Model dalam penelitian ini tampak pada gambar dibawah ini:

Gambar 1

\section{Kerangka Pemikiran}

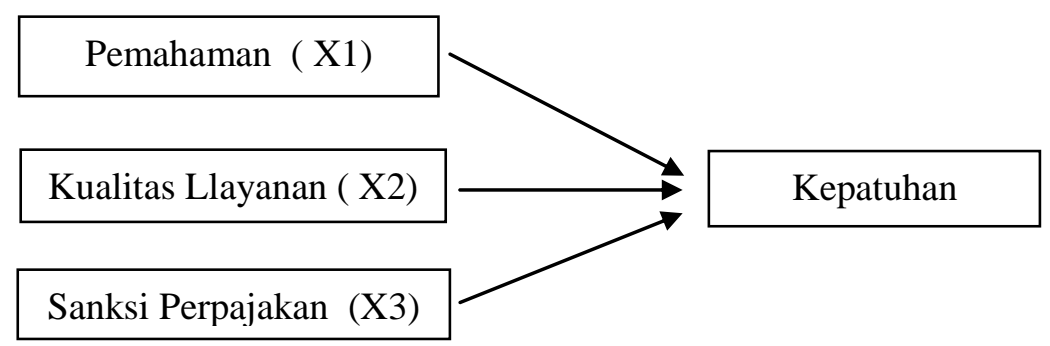

\section{METODOLOGI PENELITIAN}

Penelitian ini menggunakan metode survei, yaitu suatu penelitian dengan cara pengambilan sampel dari suatu populasi tertentu dengan menggunakan kuesioner sebagai alat pengumpul data yang dibagikan secara langsung kepada responden. Penelitian dilakukan dengan menyebarkan kuesioner ke WP yang terdaftar di KPP Pratama Wonosari. 
Subejek dalam penelitian ini adalah WP yang terdaftar di KPP Pratama Wonosari. Sampel dalam penelitian ini adalah WP yang terdaftar di KPP Pratama Wonosari. Lokasi penelitian perpusat di KPP Pratama Wonosari. Alasan pemilihan lokasi karena banyak pelaku UMKM di Wonosari sekaligus juga belum pernah adanya peneltian tentang kepatuhan UMKM di wilayah tersebutu (hasil wawancara). Selanjutnya penelitian ini akan berlangsung selama 2 minggu.

\section{Definisi Operasional}

Pemahaman WP terhadap peraturan perpajakan adalah cara WP dalam memahami peraturan perpajakan yang telah ada, Kualitas layanan adalah pelayanan yang dapat memberikan kepuasan kepada pelanggan dan tetap dalam batas memenuhi standar pelayanan yang dapat dipertangggung jawabkan serta harus dilakukan secara terus menerus Hardiningsih (2011).) Sanksi merupakan hukuman negatif kepada orang yang melanggar peraturan, sehingga dapat dikatakan bahwa sanksi perpajakan adalah hukuman negatif kepada orang yang melanggar peraturan dengan cara membayar uang.Kepatuhan berarti tunduk atau patuh pada ajaran atau aturan Jotopurnomo dan Mangoting (2013), sedangkan Kepatuhan adalah WP yang taat dan memenuhi serta melaksanakan kewajiban perpajakannya sesuai dengan ketentuan peraturan perundangundangan perpajakan Nafsi (2014).

\section{Metode Analisis Data}

Metode analisis data dalam penelitian ini adalah analisis deskriptif dan analisis regresi berganda mengunakan alat analisis dengan aplikasi Package for social Science (SPSS). Persamaan model regresi berganda tersebut, yaitu:

$$
\mathrm{Y}=\mathbf{a}+\boldsymbol{\beta}_{1} \mathrm{X} 1+\beta_{2} \mathrm{X} 2+\beta_{3} \mathrm{X} 3+\mathrm{e}
$$

$$
\begin{array}{ll}
\text { Keterangan: } & \\
\mathrm{Y} & =\text { Kepatuhan WP } \\
\mathrm{X} 1 & =\text { Pemahaman } \\
\mathrm{X} 2 & =\text { Kualitas pelayanan } \\
\mathrm{X} 3 & =\text { Sanski Perpajakan } \\
\beta_{1}, \beta_{2}, \beta_{3} & =\text { Konstanta } \\
\mathrm{e} & =\text { erorr }
\end{array}
$$

\section{HASIL PENELITIAN DAN PEMBAHASAN Hasil Pengumpulan Data}

Pengumpulan data dalam penelitian ini dilakukan dengan menyebarkan kuisioner kepada WP pelaku UMKM yang terdaftar di KPP Pratama Wonosari. Jumlah WP pelaku UMKM yang terdaftar di KPP Pratama Wonosari yaitu 5.629 orang. Terdiri dari WPOP 3.837 orang dan WP badan 1.792 .

Tabel 2

Distribusi Kuisioner

\begin{tabular}{lcc}
\hline \multicolumn{1}{c}{ Keterangan } & Jumlah & Presentase \\
\hline Kuisioner yang disebar & 105 & $100 \%$ \\
Kuisinoner yang kembali & 97 & $92,39 \%$ \\
Kuisioner yang gugur & 0 & 0 \\
Kuisioner yang dapat diolah & 97 & $92,39 \%$ \\
\hline
\end{tabular}

Sumber: data diolah

Dari tabel 2 menjelaskan bahwa kuisioner yang disebar sebanyak105kuisioner. Teknik penyebaran kuisioner yaitu secara langsung ke responden ada yang langsung diisi ditempat ada beberapa yang dibawa pergi sehingga kuisioner yang kembali sebanyak 97 kuisioner. Dengan demikian, tingkat pengembalian yang diperoleh adalah 92,39\%
Sehingga kuisioner yang dapat diolah sebanyak 97 kuisioner atau 92,39\% dari total kuisioner yang disebar. 


\section{Deskrisi Data Identitas Responden Karateristik data}

Kareteristik yang dimaksud dalam hal ini adalah mengidentifikasi responden sehingga dapat mempermudah dalam penganalisaan dan pemahaman atas objek penelitian. Data identitas yang dapat diperoleh yaitu: jenis WP, jenis kelamin, usia, tingkat pendidikan, dan peredaran bruto. Berdasarkan hasil penelitian, maka identitas responden dapat diuraikan seperti berikut ini:

\section{a. Jenis WP}

Jumlah WPOP 86 orang $(88,65 \%)$ sedangkan WP badan 11 orang $(11,35 \%)$. Hal ini menunjukan bahwa mayoritas responden dalam penelitian ini adalah WPOP.

b. Jenis Kelamin

Menurut tabel 4.3 dapat diidentifikasi bahwa responden yang berjenis kelamin pria berjumlah 43 orang $(44,32 \%)$ dan responden yang berjenis kelamin wanita berjumlah 54 orang $(55,68 \%)$.Dengan demikian penelitian ini mayoritas perempuan.

c. Usia

Dari tabel 4.4 tentang karakteristik responden menurut usia, untuk usia $>20$ tahun berjumlah 5 orang $(5,15 \%)$, usia $20-30$ tahun 45 orang $(46,39 \%)$, usia $31-40$ tahun berjumlah 39 orang $(40,21 \%)$, usia 41-50 tahun berjumlah 6 Orlng $(6,18 \%)$, dan usia diatas $<50$ tahun berjumlah 2 orang $(2,07 \%)$

d. Tingkat pendidikan

Tingkat pendidikan dapat diidentifikasi bahwa mayoritas responden dalam penelitian ini berpendidikan SMA sejumlah 43 responden atau $44,32 \%$ responden yang berpendidikan S2 dan S3 tidak ada, yang berpendidikan S1 sebanyak 7 orang atau 7,22\%, yang berpendidikan D3 sebanyak 12 responden atau $12,38 \%$, D2 sebanyak 4 orang atau $4,13 \%$, yang berpendidikan D1 sebanyak 25 orang atau $25,77 \%$ dan terakhir yaitu yang tidak tamat SMA sebanyak 6 orang atau $6,18 \%$.

e. Peredaran Bruto

Karateristik responden menurut tingkat peredaran bruto, tingkat peredaran bruto kurang dari 20 jt sebanyak 29 orang atau $29,89 \%$, tingkat peredaran bruto $20-100$ jt sebanyak 49 orang atau $50,51 \%$, tingkat peredaran bruto 100 -500 jt sebanyak 11 orang atau $11,34 \%$, tingkat peredaran bruto $500-1 \mathrm{M}$ sebanyak 7 orang atau $7,21 \%$, tingkat peredaran bruto 1-2 $\mathrm{M}$ sebanyak 1 orang atau $1,03 \%$, sedangkan untuk peredaran bruto

$2-4,8 \mathrm{M}$ ada.

\section{Analisis Deskriptif}

Tabel 3

Statistik Deskriptif

\begin{tabular}{lccccc}
\hline \multicolumn{1}{c}{ Variabel } & N & Minimum & Maximum & Mean & $\begin{array}{c}\text { Std. } \\
\text { Deviation }\end{array}$ \\
\hline Pemahaman WP & 97 & 18 & 28 & 24.6392 & 2.56249 \\
Kualitas Pelayanan & 97 & 17 & 24 & 21.3711 & 2.04796 \\
Sanksi Perpajakan & 97 & 7 & 20 & 16.2062 & 3.97109 \\
Kepatuhan WP & 97 & 13 & 20 & 17.7010 & 1.93738 \\
\hline
\end{tabular}

Sumber: data diolah tahun 2015

Tabel 3 tentang Statistik deskriptif menjelaskan bahwa variabel pemahaman WP memiliki nilai minimum sebesar 18 , maxsimum sebesar 28, dengan nilai mean sebesar 24,6392dan nilai standar deviation sebesar 2,56249. Variabel kualitas pelayanan memiliki nilai minimum sebesar 17 , maxsimum 24 , dengan nilai mean sebesar 21,3711 dan nilai standar deviation 2,04796. Variabel sanksi perpajakan memiliki nilai minimum 7 dengan nilai maxsimum 20, dengan nilai mean sebesar 16,2062 dan nilai standar deviation sebesar 3,97109. Variabel kepatuhan WP mempunyai nilai minimum sebesar 17 , maxsimum sebesar 20 , dengan nilai mean 17,710 dan nilai standar deviaton sebesar 1,93738 .

\section{Uji Kualitas Data}

Data yang digunakan dalam penelitian ini sudah lolos Uji Validitas dan uji reliabilitas 
serta uji asumsi klasik. semua data yang digunakan dalam penelitian ini sudah lolos uji asumsi klasik yaitu uji Normalitas, uji multikolinearitas, danu ji heteroskedastisitas

\section{Analisis Regresi Linear Berganda}

Setelah hasil uji asumsi klasik dilakukan dan hasilnya secara keseluruhan menunjukkan model regresi memenuhi asumsi klasik, maka untuk menjawab hipotesis dilakukan analisis regresi linier berganda dengan tingkat pemahaman WP (X1), kualitas pelayanan (X2), dan sanksi perpajakan (X3) sebagai variabel independen dan kepatuhan WP (Y) sebagai variabel dependen.

\section{Pengujian Hipotesis Uji Simultan (Uji F)}

Untuk menguji pengaruh variabel independen secara simultan terhadap variabel dependen menggunakan uji F. Hasil uji F dapat dilihat dari tebel.... Bahwa secara simultan semua variable independen mempengaruhi variable dependen berikut.

\section{Tabel 4}

\begin{tabular}{llrrrrr}
\multicolumn{7}{c}{ ANOVA $^{\text {b }}$} \\
\hline \multirow{2}{*}{ Model } & & Sum of & & & & \\
\hline 1 & Squares & df & & Mean Square & \multicolumn{1}{c}{ F } & Sig. \\
\hline & Regression & 254.719 & 3 & 84.906 & 74.768 & $.000^{\text {a }}$ \\
& Residual & 105.611 & 93 & 1.136 & & \\
& Total & 360.330 & 96 & & & \\
\hline
\end{tabular}

a. Predictors: (Constant), sanksi, kualitas, pemahaman

b. Dependent Variable: kepatuhan

\section{Uji Parsial (Uji t)}

Uji Parsial (Uji t) Pengujian ini bertujuan untuk memastikan apakah variabel independent yang terdapat dalam persamaan tersebut berpengaruh terhadap nilai variabel dependen (Adiputra 2014). Uji t dilakukan dengan membandingkan antara $t$ hitung dengan $\mathrm{t}$ tabel. Untuk menentukan nilai $\mathrm{t}$ tabel ditentukan dengan tingkat signifikasi 5\% dengan derajat kebebasan $\mathrm{df}=(\mathrm{n}-\mathrm{k}-1)$.

Tabel 5

Coefficients

\begin{tabular}{|c|c|c|c|c|c|c|c|c|c|c|}
\hline \multirow{2}{*}{ Mode } & \multicolumn{2}{|c|}{$\begin{array}{l}\text { Unstandardized } \\
\text { Coefficients }\end{array}$} & \multirow{2}{*}{$\begin{array}{c}\begin{array}{c}\text { Standardized } \\
\text { Coefficients }\end{array} \\
\text { Beta }\end{array}$} & \multirow{2}{*}{$\mathbf{T}$} & \multirow{2}{*}{ Sig. } & \multicolumn{3}{|c|}{ Correlation } & \multicolumn{2}{|c|}{$\begin{array}{c}\text { Collinearity } \\
\text { Statistics }\end{array}$} \\
\hline & B & $\begin{array}{l}\text { Std. } \\
\text { Erorr }\end{array}$ & & & & $\begin{array}{l}\text { Zero- } \\
\text { order }\end{array}$ & partial & Part & Tolerance & VIF \\
\hline 1.(Constant) & .740 & 1.158 & & .639 & .524 & & & & & \\
\hline Pemahaman & .369 & .083 & .488 & 4.456 & .000 & .815 & .419 & .250 & .263 & 3.801 \\
\hline Kualitas & .352 & .096 & .372 & 3.663 & .000 & 787 & .355 & .206 & .306 & 3.269 \\
\hline Sanksi & .022 & .031 & .045 & .705 & .483 & .368 & .073 & .040 & .764 & 1.308 \\
\hline
\end{tabular}

Sumber: data diolah tahun 2015

Dari tabel 5 tampak bahwa hipotesis pertama dan kedua terdukung oleh data, sedangkan hipotesis tidak signifikan, dan data tidak dapat mendukung hipotesis ketiga yang dibangun oleh peneliti.

\section{HASIL DAN PEMBAHASAN}

Hasil pengujian untuk hipotesis pertama diperoleh angka t-hitung sebesar 4,456 dengan signifikansi sebesar 0,000. Nilai signifikansi untuk variabel tingkat pemahaman WP menunjukkan nilai di bawah tingkat signifikan sebesar 0,05 dan nilai t-hitung sebesar 4,456 > dari t-tabel sebesar 1, 289 yang berarti bahwa hipotesis di terima atau tingkat pemahaman peraturan pajak WP berpengaruh positif dan signifikan terhadap kepatuhan WP. Penelitian ini didukung oleh Widayati dan Nurlis (2010) 
yang mennjukan bahwa pemahaman berpengaruh positif terhadap kepatuhan WP.

Hasil pengujian untuk hipotesis kedua diperoleh angka t-hitung sebesar 3,663 dengan signifikansi sebesar 0,000. Nilai signifikansi untuk variabel kualitas pelayanan menunjukkan nilai di bawah tingkat signifikan sebesar 0,05 dan nilai t-hitung sebesar 3,663 > dari t-tabel sebesar 1,289 yang berarti bahwa hipoteis diterima atau kualitas pelayanan fiskus berpengaruh positif dan signifikan terhadap kepatuhan WP. Penelitian ini didukung oleh Fikriningrum (2012) yang menunjukan bahwa kualitas layanan perpengaruh terhadap kepatuhan WP.

Hasil pengujian untuk hipotesis ketiga diperoleh angka t-hitung sebesar 0,705 dengan signifikansi sebesar 0,483. Nilai signifikansi untuk variabel sanksi perpajakan menunjukkan nilai di atas tingkat signifikan sebesar 0,05 dan nilai t-hitung sebesar $0,705<$ dari t-tabel sebesar 1,289 yang berarti bahwa hipoteis ditolak atau sanksi perpajakan tidak berpengaruh positif terhadap kepatuhan WP. Hal ini didukung oleh penelitian yang dilakukan Haryuda (2013) yang menyatakan bahwa sanksi perpajakan tidak berpengaruh positif terhadap kepatuhan WP. Dalam penelitian Jayanti (2013) menyatakan bahwa sanksi pajak bagi WP tidak berpengaruh secara signifikan terhadap kepatuhan WPOP. Selain itu penelitian yang dilakukan Monica (2013) juga menyatakan bahwa penerapan sanksi perpajakan tidak berpengaruh atau pengaruhnya sangat kecil sekali dalam meningkatkan kepatuhan WP badan dalam membayar dan melaporkan kewajiban perpajakannya. Dalam penelitian kali ini sanksi perpajakan tidak berpengaruh positif bisa disebabkan pelaku UMKM merasa sudah terbebani dengan tarif $1 \%$ dari peredaran bruto yang tidak memperhatikan apakah UMKM tersebut memperoleh laba atau tidak. Karena dalam melakukan usaha tidak akan selalu mendapatkan keuntungan apalagi pelaku usaha yang eksistensinya masih rendah.

\section{PENUTUP}

\section{Kesimpulan}

Penelitian ini bertujuan untuk mengetahui pengaruh pemahaman pajak WP, kualitas pelayanan dan sanksi perpajakan terhadap kepatuhan WP pelaku UMKM di KPP Pratama Wonosari. Berdasarkan hasil penelitian yang dikemukakan dalam bab sebelumnya, maka kesimpulan yang dapat ditarik oleh penulis adalah sebagai berikut :

1. Pengaruh pemahaman WP berpengaruh positif dan signifikan terhadap tingkat kepatuhan WP.

2. Kualitas pelayanan berpengaruh positif dan signifikan terhadap tingkat kepatuhan WP.

3. Sanksi perpajakan tidak berpengaruh positif terhadap kepatuhan WP.

4. Pemahaman, kualitas pelayanan dan sanksi perpajakan secara simultan berpengaruh terhadap kepatuhan WP.

5. Kemampuan variabel independen ini menjelaskan besarnya pengaruh terhadap variabel dependen sebesar $70,7 \%$ sementara $29,3 \%$ dijelaskan oleh variabel lain yang tidak digunakan dalam penelitian ini.

\section{Saran}

Adapun saran yang dapat penulis berikan berkaitan dengan penelitian ini adalah sebagai berikut:Dirjen Pajak (Pemerintah) untuk lebih banyak melakukan sosialisasi pajak baik peraturan, tata cara perpajakan yang baik, sanksi atau denda, tarif dan lain-lain kepada pelau UMKM khususnya yang eksistensinya masih rendah, Penyebar luasan trobosan baru yang menyeluruh kepada seluruh WP agar WP merasakan keringanan yang diharapkan, Pembuatan sektor pajak di wilayah pedusunan untuk efisiensi waktu WP UMKM.Bagi WPSaat ini pajak merupakan pendapatan terbesar negara. Sudah selayaknya kita patuh dan taat untuk melakukan pembayaran pajak.Dari hasil penelitian analisis diketahui bahwa variabel pemahaman WP miliki pengaruh yang besar terhadap kepatuhan WP, maka sebaiknya WP lebih memperluas pemahamanya tentang perpajakan agar lebih patuh dalam memenuhi kewajiban perpajakannya di kemudian hari. Hal ini dapat dilakukan dengan cara WP aktif dalam segala hal misalnya aktif bertanya kepada 
pegawai pajak tentang peraturan baru dan sebagainya.Bagi Peneliti SelanjutnyaPeneliti yang tertarik untuk melakukan kajian di bidang UMKM sebaiknya tidak memakai variabel yang sudah terdapat dalam penelitian ini. Karena masih banyak variabel bebas yang terkait.Penelitian selanjutnya hendaknya menambah indikator (jumlah item pertanyaan) untuk setiap variabel penelitian, agar hasil penelitian lebih baik lagi. Karena dalam penelitian masih ada pengaruh $29,3 \%$ dari faktor lain.Penelitian selanjutnya sebaiknya menambah responden agar hasil yang didapat lebih baikPenelitian selanjutnya melakukan penelitian lebih dari satu lokasi sehingga dapat dibandingkan dan dapat dianalisis

\section{DAFTAR PUSTAKA}

.Peraturan Pemerintah Republik

Indonesia Nomor 46 Tahun

2013tentang Pajak Penghasilan atas

Penghasilan dari Usaha yang Diterima

atau Diperoleh WP yang Memiliki

Peredaran Bruto Tertentu

Arum, Puspa Harjanti 2012. Pengaruh Kesadaran WP, Pelayanan Fiskus, dan Sanksi Perpajakan terhadap Kepatuhan WPOP yang Melakukan Kehiatan usaha dan Pekerjaan Bebas. Skripsi Universitas Diponegoro. Tidak Dipublikasikan

Adiputra, Hermawan. 2014pengaruh Tingkat Pemahaman Peraturan Pajak WP dan Kualitas Pelayanan Fiskus Terhadap tingkat Kepatuhan WP PPh Pasal 25 Badan. Skripsi Universitas Hasanudin. Tidak Dipublikasikan

Bahri, Syamsul (2013). Upaya Meningkatkan Tingkat KepatuhanSPT Tahunan PPh OP pada Kantor Pelayanan Pajak Pratama Medan Belawan.STIE Harapan Medan. Jurnal Keuangan dan Bisnis Vol.5, No. 1

Fikriningrum, Winda Kurnia. 2012. Analisis Faktor-faktor yang Mempengaruhi Wajb Pajak OP dalam Memenuhi Kewajiban Membayar Pajak. Skripsi Universitas Diponegoro Semarang.
Hardiningsih, Pancawati. 2013. Faktor- faktor yang mempengaruhi Kemauan Membayar Pajak. Universitas Stikubank. Dinamika Keuangan dan Perbankan, Vol. 3, No. 1

Harduya, Anggara Agil. 2013. Pengatuh Tingkat Kesadaran, Pengetahuan dan Pemahaman Peraturan Perpajakan, Kondisi Keuangan serta Tarif Pajak terhadap Kepatuhan Membeyar Pajak WP Badan. Skripsi Universitas Muhammadiyah Surakarta. Tidak Dipublikasikan

Jatmiko , Agus Nugroho (2006), Pengaruh Sikap WP Pada Pelaksanaan Sanksi Denda, Pelayanan Fiskus dan Kesadaran Perpajakan Terhadap Kepatuhan WP: Studi Empiris WPOP di Kota Semarang.Tesis. Program Pasca Sarjana Magister Sains Akuntansi Universitas Diponegoro.

Jayanti, Silvia Veri (2013). Pengaruh Kesadaran WP, Kemauan Membayar Pajak, Pelayanan Fiskus, Pengetahuan Akan Peraturan Perpajakan, Presepsi atas Efektifitas Sistem Perpajakan, Sanksi Pajak terhadap Kepatuhan WPOP yang Melakukan Pekerjaan Bebas. Thesis.

Jotopurnomo, Cindy dan Mangoting, Yenni. 2013.Pengaruh Kesadaran WP, Kualitas Pelayanan Fiskus, Sanksi Perpajakan, Lingkungan WP Berada terhadap Kepatuhan WPOP di Surabaya. TAX \& ACCOUNTING REVIEW, VOL.1, NO.1, 2013

Julianti, Murni (2014). Analisis Faktor-Faktor yang Mempengaruhi Kepatuhan WPOP untuk Membayar Pajak dengan Kondisi Keuangan dan Preferensi Resiko WP sebagai Variablel Modereting. Skripsi Universitas Diponegoro. Tidak Dipublikasikan

Monica (2013), Pengaruh Penerapan Sanksi Perpajakan dalam Meningkatkan Kepatuhan WP Badan. Thesis. Universitas Kristen Maranatha. 
Nafsi, Soraya Dhabtun. 2014. Pengaruh Pelayanan Fiskus, Sanksi Perpajakan, dan Kesadaran WP Terhadap Kepatuhan WP Pelaku UMKM Sesudah Penerapan Peraturan Pemerintah No.46 Tahun 2013. Skripsi Universitas Muhammadiyah Surakarta. Tidak Dipublikasikan

Oentari, Arabella Fuadci dan Mangoting, Yenni. 2013. Pengaruh Kualitas Pelayanan Petugas Pajak, Sanksi Perpajakan dan Biaya Kepatuhan Pajak Terhadap Kepatuhan WP UMKM.Tax \& Accounting Review, VOL.1, NO.1

Prabawati, Kiki. 2012. Peranan Tutor dalam Pengembangan Kemandirian Usaha Warga Belajar Program Keaksaraan Usaha Mandiri (KUM) di PKBM Ingin Wasis Temon Wetan Kulonprogo Yogyakarta. Skripsi Universitas Negri Yogyakarta. Tidak Dipubllikasikan

Pranadata, I Gede Putu.2014.Pengaruh Pemahaman WP, Kualitas Pelayanan dan Pelaksanaan Sanksi Pajak terhadap Kepatuhan WPOP pada KPP Pratama Batu. Universitas Brawijaya. Jurnal Ilmiah Vol.2 No2

Putra, Adi. 2009. Pengaruh Kualitas Pelayanan Terhadap Kinerja Kerelasian Nasabah. Universitas Negri Malang. Jurnal Ekonomi Bisnis, Vol.14,No.2

Rahayu, Sri. 2009. Pengaruh Modernisasi Sistem Akuntansi Perpajakan terhadap Kepatuhan WP. Jurnal Akuntansi Universitas Kristen Maranatha, Vol.1, No2

Rutiyaningsih, Sri. 2011. Faktor-faktor yang mempengaruhi Kepatuhan WP. Universitas Katolik Widyamandala Madiun. Widya Warta No.2

Saepudin, Ade . 2012. Pengaruh Pemahaman Akuntandi dan Ketentuan Perpajakan Serta Transparansi dalam Pajak terhadap Kepatuhan WP Badan. Universitas Siliwangi. Tidak Dipublikasikan
Supadmi, Ni Luh. 2009. Meningkatkan Kepatuhan WP melalui KualitasPelayanan. Universitas Udayana Bali.

Triyanto, Agus Andiran. 2013. Pengaruh Kualitas Pelayanan Pajak terhadap Kepatuhan WPOP. Universitas Brawijaya. Jurnal Ilmiah Vol.1, No.2

Wayan, I Mustika Utama.2011. Pengaruh Kualitas Pelayanan, Sanksi Perpajakan dan Biaya Kepatuhan terhadap Kepatuhan WP. Universitas Udayana Bali

Widayati dan Nurlis, SE.AK.Msi. 2010. FaktorFaktor Yang Mempengaruhi Kemauan Untuk Membayar Pajak WPOP Yang Melakukan Pekerjaan Bebas (Studi Kasus Pada Kpp Pratama Gambir Tiga): Universitas Jenderal Soederman. Jurnal dan Prosiding SNA - Simposium Nasional Akuntansi Vol.13,

www.anggaran. depkeu.go.id

www.pajak.go.id

www. Wikipedia.com

Zahidah, Choiriyatuz. 2010. Pengaruh Tingkat Pemahaman dan Ketegasan sanksi Perpajakan terhadap Kewajiban Perpajakan Pengusaha Usaha Kecil dan Menengah (UKM) di Wilayah Jakarta Selatan. Skripsi Universitas Islam Negri Syarif Hidayatullah. 